To Maega | Jurnal Pengabdian Masyarakat

Februari 2021, Vol. 4, No. 1, hal 1-13

$\operatorname{ISSN}(P): 2622-6332 ; \operatorname{ISSN}(E): 2622-6340$

http://www.ojs.unanda.ac.id/index.php/tomaega

\title{
Digitalisasi UMKM berbasis Retail melalui Program Hibah RISTEK-BRIN
}

\author{
Lauentinus ${ }^{1}$, Okkita Rizan 2,", Hamidah 3, Sarwindah 4 \\ ${ }^{1}$ Teknik Informatika, Fakultas Teknologi Informasi, ISB Atma Luhur \\ ${ }^{2}$ Sistem Informasi, Fakultas Teknologi Informasi, ISB Atma Luhur \\ ${ }^{3}$ Manajemen Informatika, Fakultas Teknologi Informasi, ISB Atma Luhur \\ ${ }^{4}$ Bisnis Digital, Fakultas Ekonomi Bisnis, ISB Atma Luhur \\ *Correspondent Email: orizan@atmaluhur.ac.id
}

\author{
Article History:
}

Received: 26-7-2020; Received in Revised: 16-8-2020; Accepted: 18-8-2020

DOI: http://dx.doi.org/10.35914/tomaega.v4i1.418

\begin{abstract}
Abstrak
UMKM merupakan salah satu bisnis yang dapat dibangun dan dijalankan oleh siapa saja, karena model bisnis ini dapat diterapkan dengan tidak memerlukan modal dan tempat usaha yang sangat besar. UMKM cukup menjanjikan jika dapat dikelola dengan baik. Tetapi, pada umumnya UMKM dengan modal yang tidak begitu besar, menimbulkan permasalahan tersendiri bagi UMKM ini. Kendala yang dihadapi oleh UMKM diantaranya sulit untuk mengontrol kegiatan usaha dan operasionalnya, mulai dari tahap persiapan sampai dengan penyajian laporan. Efeknya, UMKM mengalami hambatan dalam menentukan skenario terbaik untuk mengembangkan usahanya di masa depan. RISTEK-BRIN hadir untuk membantu mengatasi permasalahan ini, yaitu dengan menyediakan aplikasi berbasis komputer hasil kolaborasi dengan perguruan tinggi, sehingga kegiatan bisnis dapat dikelola dengan lebih baik. Metode yang dilaksanakan untuk menerapkan aplikasi ini diantaranya survey langsung terhadap kebutuhan layanan yang cocok dengan bisnis UMKM, mengembangkan prototipe aplikasi, mencari UMKM yang sangat memerlukan, melakukan ujicoba aplikasi dan sekaligus memberikan pelatihan bagi UMKM untuk menggunakan aplikasinya. Melalui penerapan aplikasi ini, dapat diketahui bahwa UMKM sangat terbantu dalam mengelola usaha bisnisnya walaupun diperlukan beberapa trik tambahan, dikarenakan sebagian besar pengguna UMKM belum terbiasa menggunakan aplikasi berbasis digital ini.
\end{abstract}

Kata Kunci: UMKM, Digitalisasi, Ristek-BRIN

\begin{abstract}
UMKM is one of the businesses that can be built and run by anyone because this business model can be applied without the need for capital and a very large place of business. UMKM is quite promising if it can be managed well. But, in general, UMKM with capital that is not so large, cause its problems for UMKM. The obstacles faced by UMKM are difficult to control their business and operational activities, starting from the preparation stage to the presentation of reports. The effect is that UMKM faces obstacles in determining the best scenario to develop its business in the future. RISTEK-BRIN is here to help overcome this problem, namely by providing computer-based applications in collaboration with universities, so that business activities can be better managed. The methods implemented to implement this application include direct surveys of service
\end{abstract}


needs that are compatible with UMKM businesses, developing application prototypes, looking for UMKM that need it, conducting application trials, and simultaneously providing training for UMKM to use their applications. Through the application of this application, it can be seen that UMKM is greatly helped in managing their business ventures, although some additional tricks are needed because most UMKM users are not accustomed to using digital-based applications.

Key Word: UMKM, Digitalization, Ristek-BRIN

\section{Pendahuluan}

Usaha Mikro Kecil Menengah atau biasa disebut dengan UMKM, adalah salah satu bentuk usaha yang dapat dikelola langsung masyarakat umum, tanpa harus mengurus perizinan pendirian perusahaan yang rumit. Secara umum, definisi UMKM telah disebutkan secara khusus dalam Undang-Undang. Pengertian UMKM tertuang pada Undang-Undang Republik Indonesia No.20 Tahun 2008 tentang UMKM. Pada Pasal 1 dari Undang Undang tersebut, diuraikan ada tiga hal pokok mengenai perbedaan dari usaha mikro, usaha kecil dan usaha menengah.

Pasal tersebut menyatakan bahwa usaha mikro adalah sebuah usaha produktif milik orang perorangan dan/atau badan usaha perorangan yang memiliki kriteria usaha mikro sebagaimana diatur dalam UU dimaksud. Pada pasal tersebut, usaha kecil dinyatakan adalah usaha ekonomi produktif yang berdiri sendiri, yang dilakukan oleh orang perorangan atau badan usaha yang bukan merupakan anak perusahan atau bukan anak cabang yang dimiliki, dikuasai atau menjadi bagian, baik langsung maupun tidak langsung, dari usaha menengah atau usaha besar yang memenuhi kriteria usaha kecil sebagaimana dimaksud dalam undang-undang dimaksud.

Sedangkan, definisi usaha menengah adalah usaha ekonomi produktif yang berdiri sendiri, yang dilakukan oleh orang perorangan atau badan usaha yang bukan merupakan anak perusahaan atau cabang perusahaan yang dimiliki, dikuasai, atau menjadi bagian baik langsung maupun tidak langsung dengan usaha kecil atau usaha besar dengan jumlah kekayaan bersih atau hasil penjualan tahunan sebagaimana diatur dalam undang-undang dimaksud.

Berdasarkan data yang dikeluarkan oleh Badan Pusat Statistik, pada tahun 2016 UMKM mampu menyerap setidaknya 89,2 dari total tenaga kerja. UMKM juga tercatat menyumbang sebanyak 60,34 dari total PDB nasional. Bukti tersebut menunjukkan bahwa ketangguhan dari UMKM yang tidak dapat dipandang sebelah mata. UMKM biasa dirintis dari lingkup yang paling kecil, seperti modal yang tidak begitu besar dan tempat usaha dengan fasilitas seadanya. Dengan kiat dan trik tertentu, UMKM dapat diramu sedemikian rupa sehingga menjadi sebuah UMKM dengan omset yang menjanjikan.

Menurut Suriyati (2019), menyebutkan bahwa UKM mempunyai peran yang sangat strategis dalam pembangunan ekonomi di negara-negara berkembang. Karena, CTo Maega / Jurnal Pengabdian Masyarakat. This is an open access article under the CC BY-SA 4.0 license (https://creativecommons.org/licenses/by-sa/4.0/). 
saat ini pun, UKM sudah dapat meningkatkan pangsa pasar mereka dengan melakukan perdagangan secara eletronik sehingga transaksi dapat dilakukan secara online dan pelanggan dapat berasal dari seluruh belahan dunia.

Mengutip dari Desrianto (2019), ada beberapa fakor yang dapat dijadikan acuan dalam mengelola dan meningkatkan omset sebuah UMKM, meliputi diantaranya keahlian/pengetahuan, kelincahan dan inovasi. Keahlian/Skill, adalah sebuah faktor utama yang harus dimiliki oleh pelaku UMKM. Pelaku UMKM diharuskan memiliki pengetahuan serta skill dalam menjalankan usaha, yaitu kemampuan memecahkan masalah yang komplek, berpikir kritis, kreativitas, memanajemen manusia, berkoordinasi dengan orang lain, kecerdasan emosional, penilaian dan pengambilan keputusan, berorientasi servis, negosiasasi dan fleksbilitas kognitif. Salah satu cara untuk dapat menambah pengetahuan bisnisnya, bisa dilakukan dengan memanfaatkan internet dalam mencari dan menciptakan peluang, kolaborasi, kreatif, meningkatkan produksi, hingga teknik berkomunikasi dengan orang lain.

Disebutkan juga oleh Mannuhung (2018), perkembangan berbagai disiplin ilmu dan teknologi sangat pesat sehingga menuntut agar setiap individu, masyarakat, kelompok ataupun organisasi mampu menghadapi perkembangan dan kemajuan tersebut. Disebutkan bahwa salah satu cara untuk menghadapi perkembangan tersebut dengan tata kelola atau manajemen yang berkualitas, sehingga pengelolaan organisasi yang baik akan mampu membawa hasil yang baik dan berkualitas.

Kemampuan kelincahan ditekankan pada kemampuan UMKM melakukan kegiatan multitasking. Penunjang kemampuan ini dapat dibantu dengan memiliki beberapa kolega, sehingga menjadi faktor penting yang tidak dapat dikesampingkan. UMKM harus memiliki jaringan yang luas dan baik. Karena penting untuk mempromosikan produk dan kelancaran kegiatan multitasking. Salah satu teknik pengumpulan jejaring tentunya dapat memanfaatkan teknologi seperti melalui media sosial. Melalui teknologi dapat melakukan transaksi jual beli hingga layanan antar kurir online dalam menyalurkan produk.

Kemampuan berinovasi bergantung pada kualitas sumber daya manusia dalam menguasai dan memanfaatkan iptek dan inovasi. Kemampuan berinovasi diperlukan, karena sekarang sudah memasuki era industri 4.0, sebuah era yang sangat bergantung pada kualitas SDM (Sumber Daya Manusia) pekerja dalam menggunakan serta memanfaatkan Teknologi dalam berinovasi dan berkreatifitas. Menurut Ardiansyah (2018), manfaat dari penerapan Ipteks adalah sebagai percontohan bagi masyarakat, sehingga bila dikaitkan dengan kegiatan pengabdian ini, UMKM akan memotivasi UMKM lain yang relevan supaya dapat berinovasi menggunakan teknologi dalam kegiatan bisnisnya.

Dari uraian tersebut, dapat diketahui bahwa teknologi memiliki peranan penting dalam membantu mengelola dan memanajemen bisnis. UMKM seolah dipaksa harus memiliki kemampuan menggunakan teknologi, ditambah sudah license (https://creativecommons.org/licenses/by-sa/4.0/). 
memasuki era industri 4.0, atau biasa disebut juga dengan era dengan teknologi digital.

Menurut Aji (2016), Teknologi digital merupakan pembaruan dari teknologi analog. Teknologi digital adalah sebuah teknologi yang tidak lagi mengandalkan tenaga manusia, atau biasa disebut dengan sistem manual. Teknologi digital lebih cenderung pada sebuah sistem pengoperasian yang dapat dijalankan secara otomatis dengan sistem yang komputerisasi atau format yang dapat dipahami oleh komputer. Sebuah sistem digital menggunakan urutan angka untuk mewakili informasi. Tidak seperti sinyal analog, sinyal digital bersifat noncontinuous.

Bagi UMKM dengan kemampuan keuangan yang cukup memadai, keharusan untuk menggunakan teknologi tidak akan menjadi kendala berarti. Karena, jika UMKM tidak mampu menguasai teknologi, mereka dapat menyewa dan menggunakan pihak ketiga yang handal dalam teknologi untuk membantu kegiatan bisnisnya. Tetapi, bagi UMKM dengan kemampuan keuangan seadanya, penggunaan teknologi akan menjadi pilihan terakhir dan hanya sebagai opsi cadangan saja, jika terpaksa dilaksanakan. UMKM dengan kemampuan terbatas ini, akan fokus mengelola bisnis seadanya daripada mereka harus berinvestasi menggunakan teknologi, karena penerapan teknologi ini tidak membutuhkan biaya sedikit. Sehingga, perlu sebuah cara untuk membantu UMKM ini. Perlu dibantu melalui sebuah skema dengan model yang terbatas, UMKM dapat menggunakan teknologi untuk mengelola bisnisnya.

Pada tahun 2019, titik terang akhirnya muncul. Pada tahun tersebut, Ristek Dikti meluncurkan beberapa program pengabdian pada masyarakat. Salah satu program pengabdian yang ditawarkan dinamai dengan Program Pengembangan Usaha Produk Intelektual Kampus (PPUPIK). Melalui program ini, perguruan tinggi diberi akses dalam wujud knowledge and technopark yang memanfaatkan pengetahuan, pendidikan maupun hasil riset dosen. Perguruan tinggi diharapkan terdorong dalam membangun akses yang menghasilkan produk jasa atau teknologi hasil ciptaannya sendiri (PPUPIK, 2019).

Atma Luhur adalah sebuah perguruan tinggi yang mempunyai beberapa program studi di bidang ilmu komputer. Berkenaan dengan skema pengabdian yang ditawarkan oleh Ristek BRIN, Atma Luhur mempunyai kesempatan untuk membantu UMKM, yaitu dengan menyiapkan teknologi berupa aplikasi komputer berbasis sistem informasi, yang menjadi ciri khas Atma Luhur.

\section{Metode}

Dalam melaksanakan dan merealisasikan program pengabdian dari Ristek Dikti tersebut, sehingga dapat menciptakan, menyalurkan dan menggunakan sistem yang akan digunakan oleh UMKM, tim pengabdian dari ISB Atma Luhur melakukan beberapa metode. Sistem yang disediakan oleh tim pengabdian adalah 
Sistem informasi berbasis komputer yang berguna untuk mengelola kegiatan bisnis UMKM.

Tim pengabdian perlu menentukan objek tempat melaksanakan kegiatan pengabdian ini, sesuai dengan petunjuk dan ketentuan dalam mengikuti program hibah Ristek BRIN ini, supaya tidak melenceng dari hasil akhir kegiatan yang telah ditetapkan. Melalui diskusi dan memperhatikan beberapa faktor, dapat ditetapkan pelaksanaan kegiatan pengabdiannya. Pengabdian akan dilaksanakan di Provinsi Kepulauan Bangka Belitung dan dilaksanakan di Kota Pangkalpinang. Rentang waktu pelaksanaan antara bulan Maret sampai dengan Juli 2020. UMKM yang diarahkan dan dapat mengikuti kegiatan pengabdian ini adalah UMKM yang mempunyai bidang bisnis yang sama, yang bertujuan untuk memudahkan menerapkan sistem yang akan digunakan. UMKM yang dipilih adalah UMKM yang mempunyai bisnis dibidang retail. Target UMKM yang akan menggunakan sistem ini adalah sebanyak 30 UMKM.

Secara umum metode yang digunakan diantaranya diuraikan berikut ini.

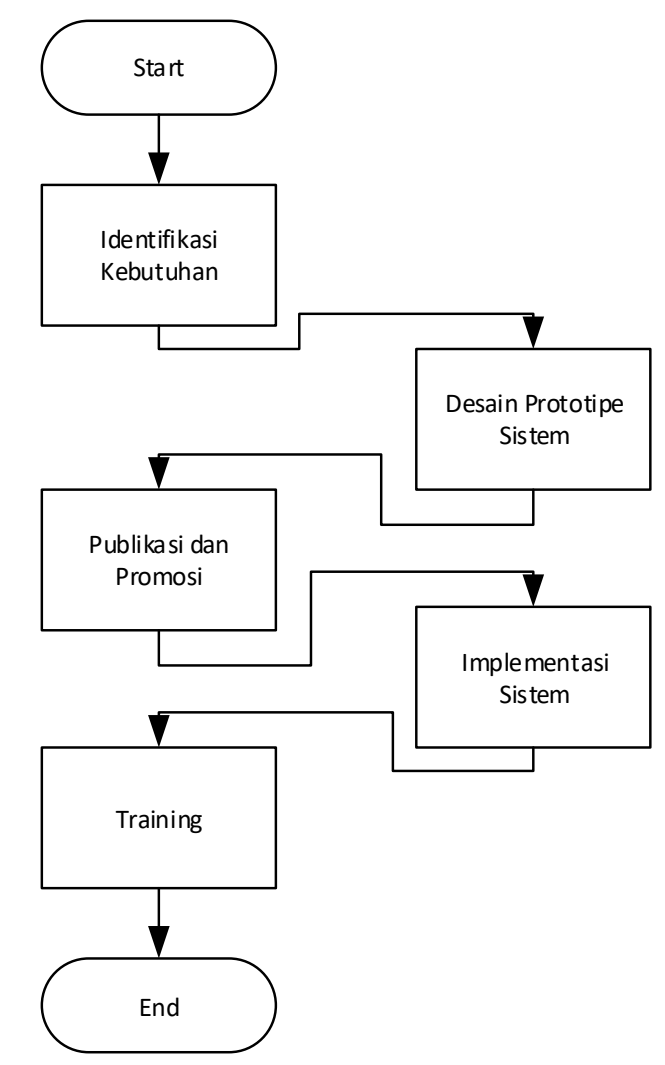

Gambar 1. Metode Pelaksanaan Pengabdian

Identifikasi kebutuhan sistem, metode ini digunakan sebagai persiapan awal untuk menentukan sejauh mana dan model sistem apa yang cocok digunakan oleh UMKM yang sedang berkembang dan UMKM yang hanya sedikit mengetahui menggunakan sistem. 
Desain prototipe sistem, metode ini digunakan sebagai desain awal sistem yang dibangun berdasarkan hasil rangkuman identifikasi terhadap kebutuhan sistem. Desain prototipe mengalami berbagai perubahan untuk mencari solusi terbaik sistem yang sesuai.

Diuraikan oleh Purnomo (2017), dibuatnya sebuah prototyping bagi pengembang sistem bertujuan untuk mengumpulkan informasi dari pengguna sehingga pengguna dapat berinteraksi dengan model prototype yang dikembangkan, sebab prototipe menggambarkan versi awal dari sistem untuk kelanjutan sistem sesungguhnya yang lebih besar.

Selain itu, ditegaskan pula oleh Ogedebe (2012), telah ditemukan bahwa dalam analisis dan desain sistem, terutama untuk proses transaksi, di mana dialog yang ditampilkan lebih mudah difahami. Semakin besar interaksi antara komputer dan pengguna, besar pula manfaat yang diperoleh ketika proses pengembangan sistem informasi akan lebih cepat dan membuat pengguna akan lebih interaktif dalam proses pengembangannya

Prototipe sistem yang dibangun untuk UMKM ini, adalah aplikasi yang berbasis web dan dibangun menggunakan framework CodeIgniter. Menurut Basuki (2010), CodeIgniter merupakan framework PHP yang dibuat berdasarkan model view Controlleer (MVC). CI memiliki library yang lengkap untuk mengerjakan operasi-operasi yang umum dibutuhkan oleh aplikasi berbasis web misalnya mengakses database, memvalidasi form sehingga sistem yang dikembangkan mudah. CI juga menjadi satu-satunya Framework dengan dokumentasi yang lengkap dan jelas. Source code CI yang dilengkapi dengan comment didalamnya sehingga lebih memperjelas fungsi sebuah kode program dan CI yang dihasilkan sangat Bersih (clean) dan search Engine Friendly (SEF).

Codeigniter juga dapat memudahkan developer dalam membuat aplikasi web berbasis PHP, karena framework sudah memiliki kerangka kerja sehingga tidak perlu menulis semua kode program dari awal. Selain itu, struktur dan susunan logis dari codeigniter membuat aplikasi menjadi semakin teratur dan dapat fokus pada fitur-fitur apa yang akan dibutuhkan dalam pembuatan aplikasi tersebut.

Publikasi dan Promosi, metode ini digunakan untuk menyampaikan ke UMKM bahwa sudah tersedia sebuah sistem yang sudah terkomputerisasi yang dapat digunakan untuk meningkatkan kegiatan bisnis UMKM. Menurut Lamb, Hair, Mc-Daniel, promosi adalah komunikasi dari para penjual yang menginformasikan, membujuk, dan mengingatkan para calon pembeli suatu produk dalam rangka mempengaruhi pendapat mereka atau memperoleh suatu respon (Jaiz, 2014).

Implementasi sistem, metode ini digunakan untuk memasang sistem dan memastikan apakah sistem yang telah dibangun dapat digunakan dan menyesuaikan karakteristik UMKM. Sedangkan pada training penggunaan sistem, metode ini digunakan untuk memastikan pengguna sistem dari UMKM sangat license (https://creativecommons.org/licenses/by-sa/4.0/). 
mampu dan dapat dengan baik menggunakan sistem yang telah diimplementasikan.

\section{Hasil dan Pembahasan}

Sebelum menghasilkan sebuah sistem berbasis digital yang dapat membantu UMKM mengembangkan roda kegiatan bisnis nya, tim pengabdian ISB Atma Luhur melakukan kegiatan penting, yaitu mencari informasi tentang sistem seperti apa yang diperlukan oleh UMKM. Dikarenakan banyak sekali jenis kegiatan bisnis yang dikelola oleh UMKM, tim pengabdian memilih salah satu jenis kegiatan bisnis yang sangat banyak dikembangkan oleh pelaku UMKM. Hal ini penting dikarenakan karakteristik setiap jenis kegiatan bisnis tentunya akan mempengaruhi desain sistem yang akan dibangun.

Jenis kegiatan bisnis yang dipilih oleh tim pengabdian ISB Atma Luhur adalah bisnis retail. Sehingga, tim pengabdian perlu berkomunikasi dan berinteraksi dengan pihak yang kompeten untuk mendapatkan data yang akurat, yang sangat diperlukan sebagai acuan mendesain sistem. Sample data dilakukan dengan cara melakukan survei langsung ke tempat UMKM yang telah memperoleh omset cukup tinggi melalui wawancara dan kegiatan observasi di lokasi tersebut. Selain itu, tim pengabdian juga mengambil beberapa referensi melalui studi kepustakaan mengenai sistem yang berkaitan dengan topik yang dipilih.

Dari hasil survei dan proses identifikasi kebutuhan sistem, tim pengabdian dapat melanjutkan ke tahapan berikutnya, yaitu menciptakan sebuah sistem dalam bentuk prototyping.

Prototipe ini akan menjadi acuan dasar dan menjadi bahan evaluasi sebelum sistem sepenuhnya dapat digunakan oleh pihak UMKM. Untuk membangun prototipe ini, tentunya meliputi beberapa tahapan. Tahapan yang dilalui diantaranya analisa sistem, desain sistem yang cepat dan testing dan evaluasi prototipe. 


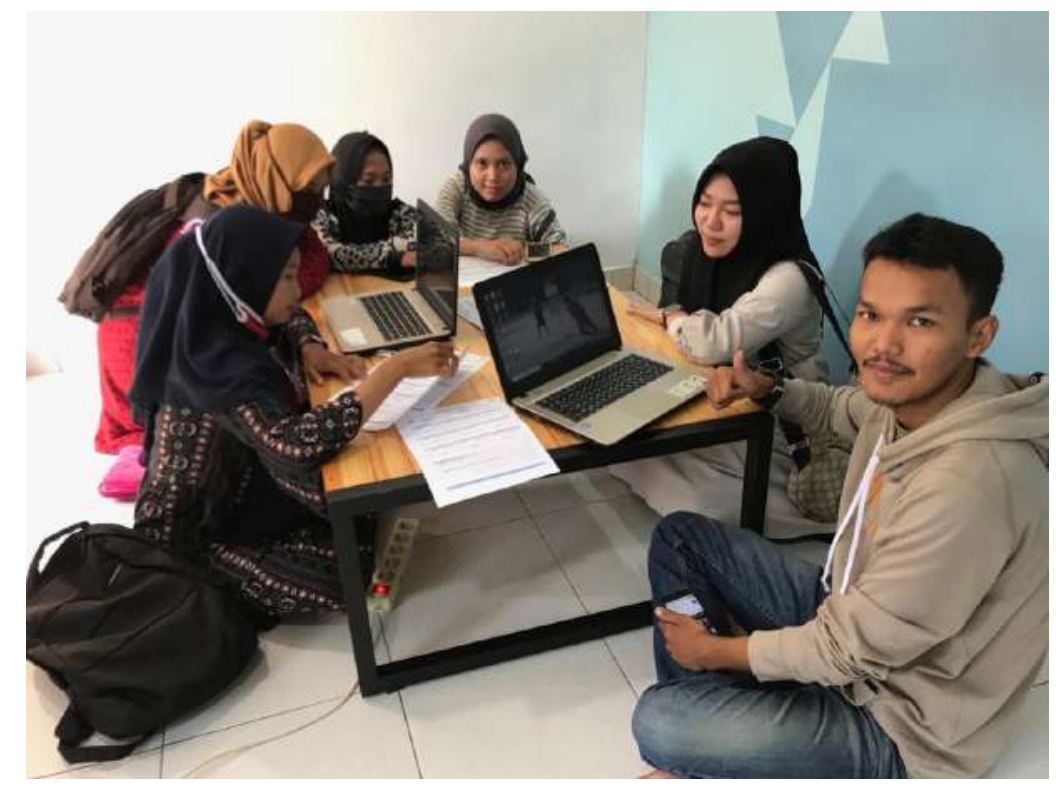

Gambar 2. Proses Identifikasi Kebutuhan dan Pembuatan Prototipe

Analisa sistem berpatokan dari hasil survei dan identifikasi kebutuhan. Analisa sistem diperlukan sebagai acuan untuk mendesain sistem yang diperlukan, sedangkan testing diperlukan sebagai tolak ukur untuk mengetahui apakah sistem yang dibuat telah memenuhi kebutuhan atau belum. Setelah melewati beberapa proses diantaranya desain form dan coding program, terbentuk sebuah sistem yang dirasa cukup ideal untuk menjawab kebutuhan UMKM. Tentunya UMKM yang berbasis retail

Prototipe sistem yang dibangun meliputi proses pendataan, proses transaksi dan proses penyajian laporan. Pada proses pendataan, sistem mampu untuk menyajikan detail sebuah produk. Melalui proses pendataan ini, UMKM dapat mengontrol produk dengan stok yang sudah minimal, sehingga dapat melakukan distribusi ulang produk tersebut. Selain itu dapat mengetahui produk yang akan memasuki masa expired.

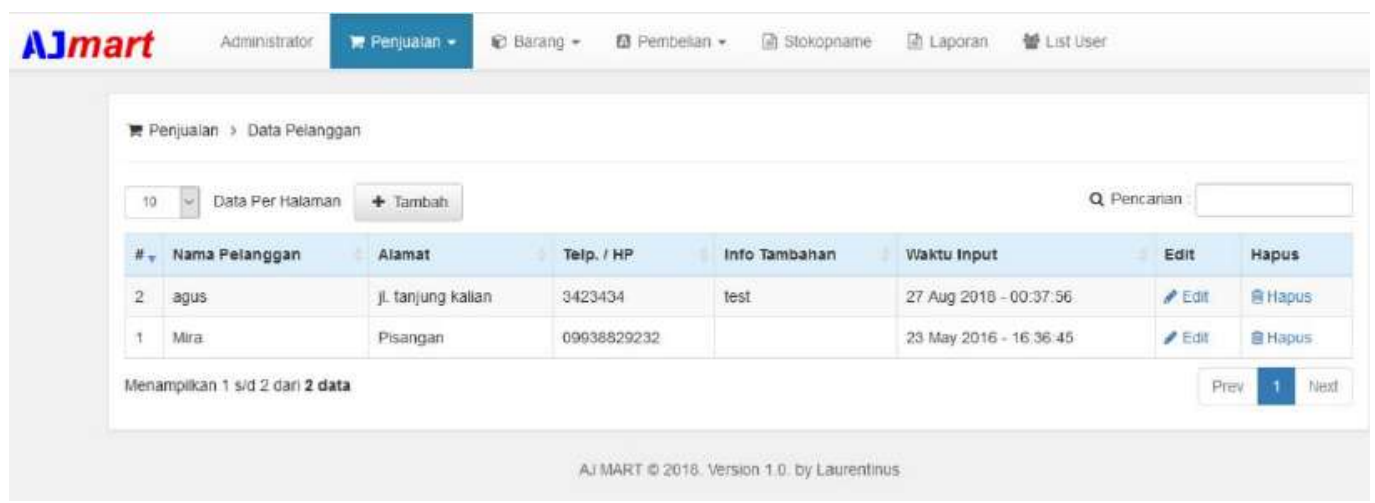

Gambar 3. Form Pendataan 
Banyak keuntungan yang disediakan pada proses transaksi, diantaranya dapat menghindari kesalahan pada saat perhitungan pembelian produk dan langsung dapat diketahui jika ada produk yang tidak mencukupi stoknya. Dengan tampilan interface yang user friendly, dapat meningkatkan jumlah produktifikas kegiatan transaksi bisnis.

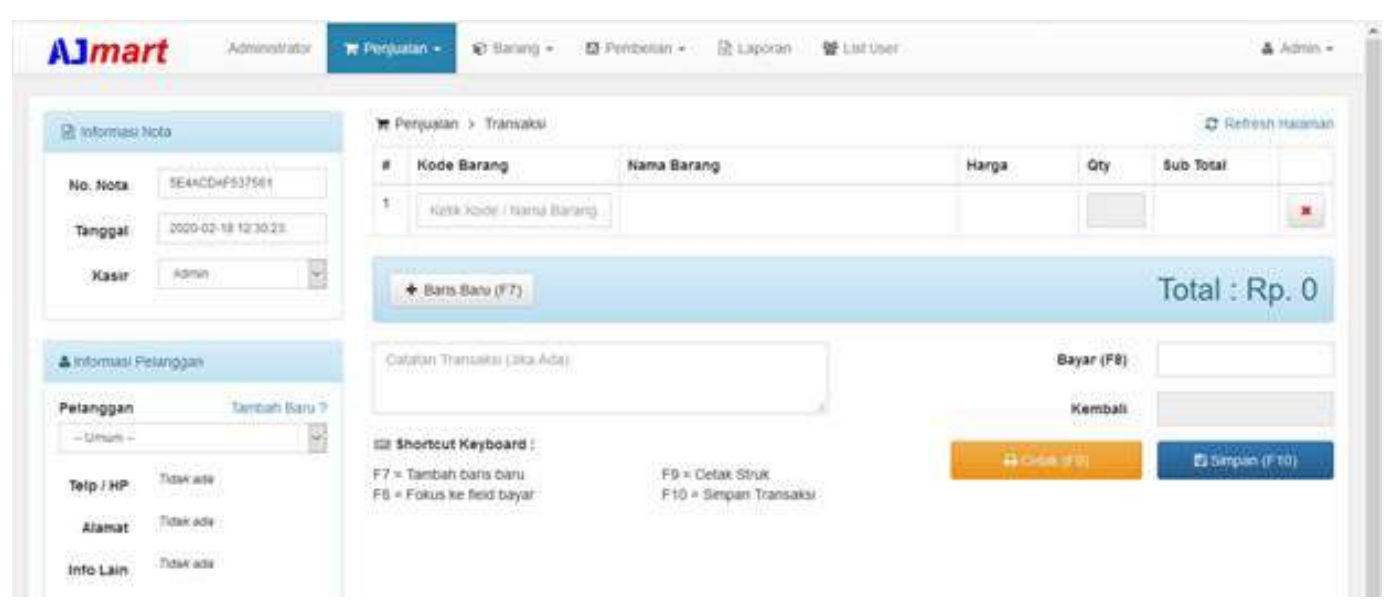

\section{Gambar 4. Form Transaksi}

Pada proses penyajian laporan, informasi penting yang dapat dipahami oleh pemilik UMKM, diantaranya dapat mengetahui dengan pasti omset yang diterima setiap bulannya. Selain itu, melalui proses laporan ini, dapat diketahui produk apa yang sangat diminati oleh pelanggan, sehingga dapat menentukan kebijakan bisnis berikutnya.

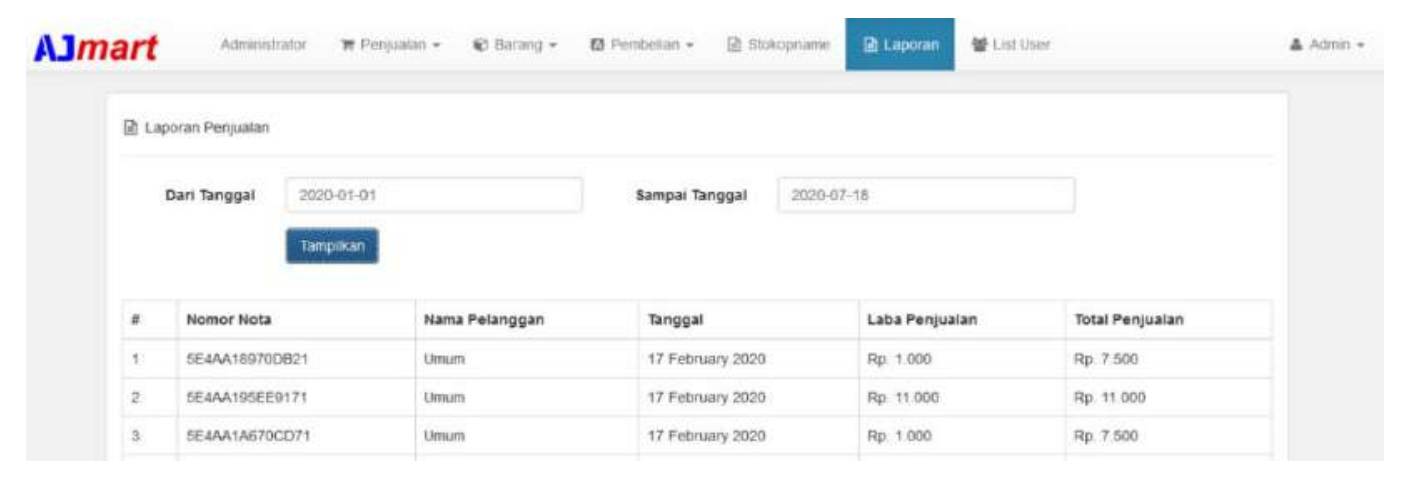

Gambar 5. Form Laporan

Dengan telah selesainya prototipe sistem ini dibangun, maka dapat dilaksanakan tahapan berikutnya. Tahapan yang dilaksanakan adalah publikasi sistem.

Point penting pada tahapan ini adalah untuk menyampaikan ke seluruh UMKM bahwa sudah tersedia sistem yang dapat digunakan dalam kegiatan bisnis mereka. Mengingat tujuan dari kegiatan ini adalah untuk mendigitalisasikan 
UMKM, maka proses publikasi pun harus dilaksanakan secara digital. Adapun cara yang digunakan adalah membuat sebuah flyer yang berisi informasi tentang sistem tersebut.
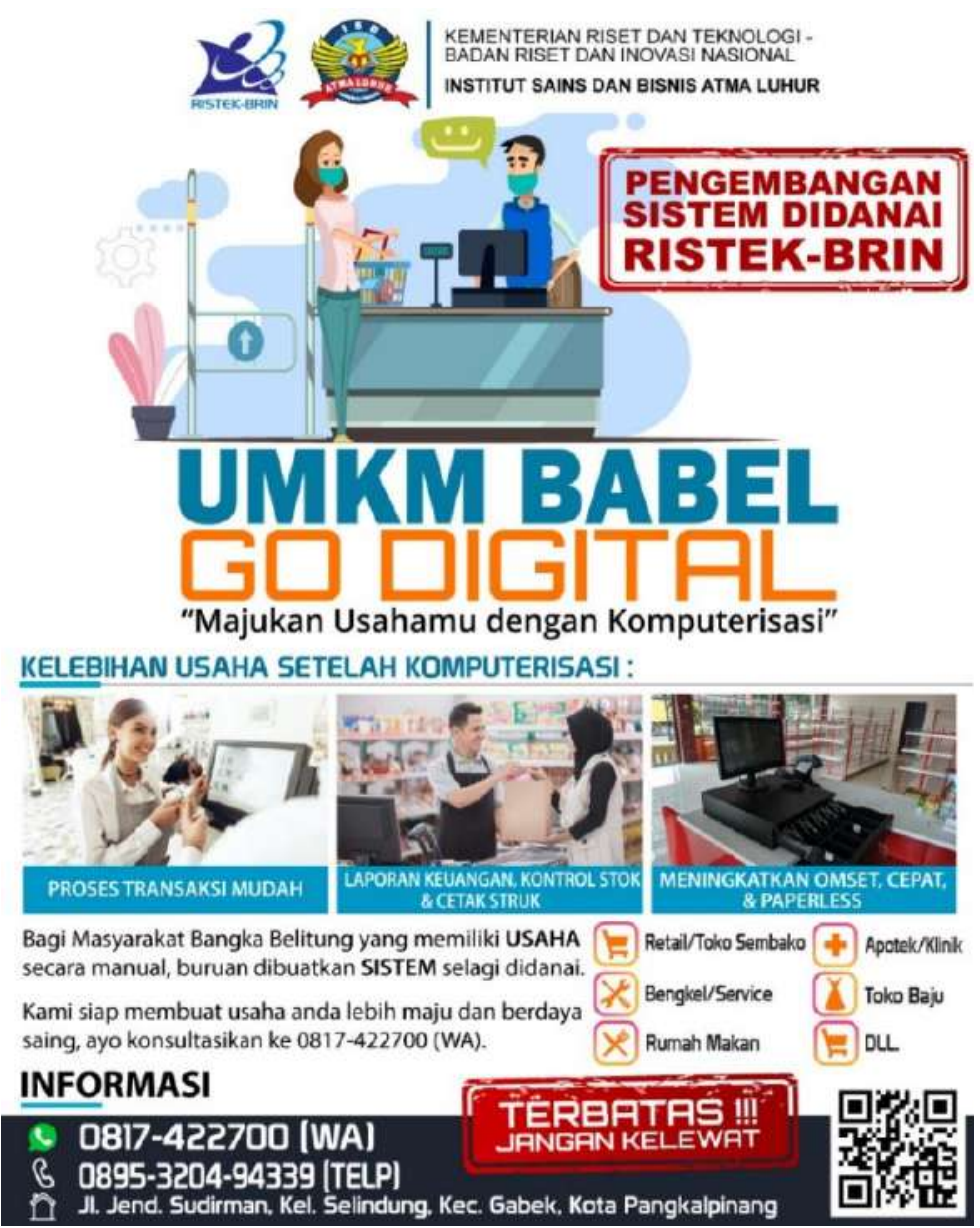

Gambar 6. Fyler Publikasi

Selain menggunakan flyer, cara lain yang cukup efektif digunakan adalah mempromosikan sistem menggunakan media massa berbasis elektronik. Media massa yang digunakan hanya berskala lokal, karena target awal UMKM yang dituju baru sebatas kota dan kabupaten di Provinsi Kepulauan Bangka Belitung. Keuntungan lain menggunakan metode ini dibandingkan dengan menyebarkan flyer adalah dapat secara lengkap menyampaikan keunggulan program RistekBRIN ini sekaligus menyampaikan syarat yang harus dipenuhi oleh pelaku UMKM apabila ingin memperoleh bantuan sistem ini. 


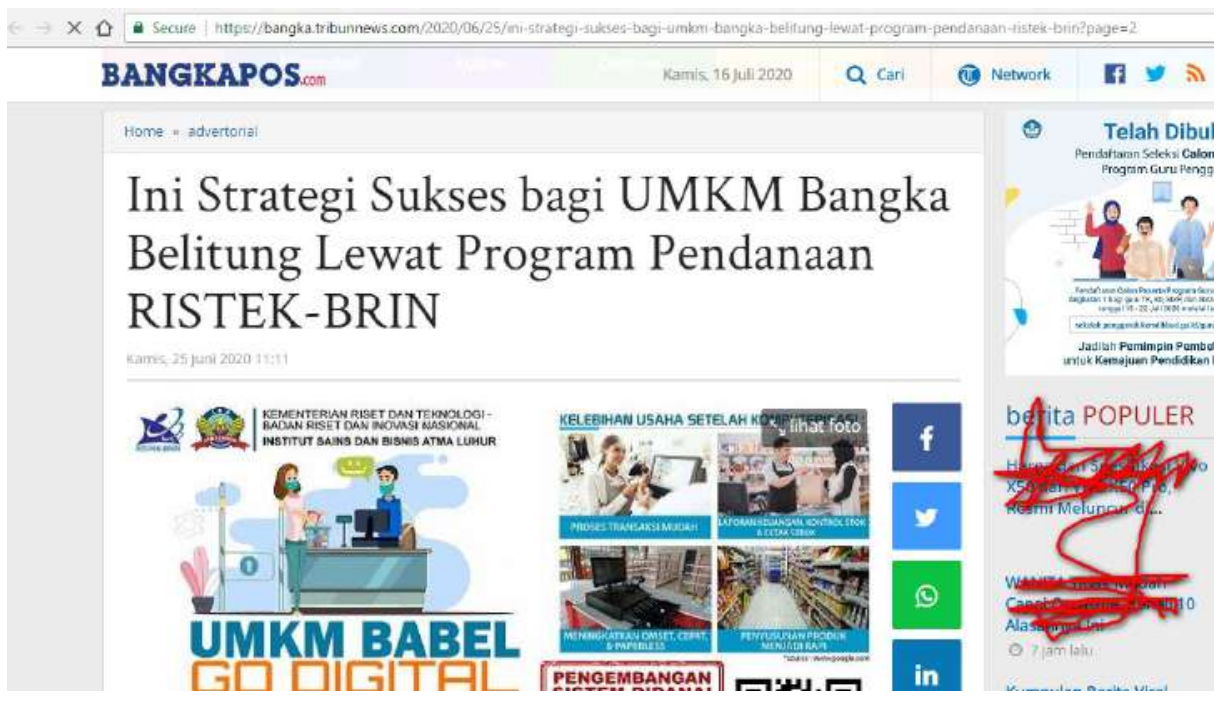

Gambar 7. Publikasi Media Massa Online

Dari hasil publikasi sistem, beberapa UMKM menunjukkan kepercayaan dan merasa perlu untuk menggunakan sistem hasil hibah ini. Karena sistem ini merupakan hasil hibah, maka tim pengabdian harus memenuhi target capaian pengguna sistem. Pada awalnya target sudah hampir terpenuhi, namun sangat disayangkan, dikarenakan kondisi pandemi covid yang belum berakhir, banyak UMKM yang mengurungkan niat bahkan membatalkan menggunakan sistem yang sudah disetujui sebelumnya, Sehingga hanya beberapa UMKM saja yang dapat melakukan proses instalasi sistem.

Beberapa pertimbangan yang jadi tolak ukur dalam melakukan proses instalasi diantaranya adalah kapasitas ruangan dan infrastruktur jaringan di lokasi UMKM. Instalasi dinyatakan selesai apabila sistem sudah siap dioperasikan.

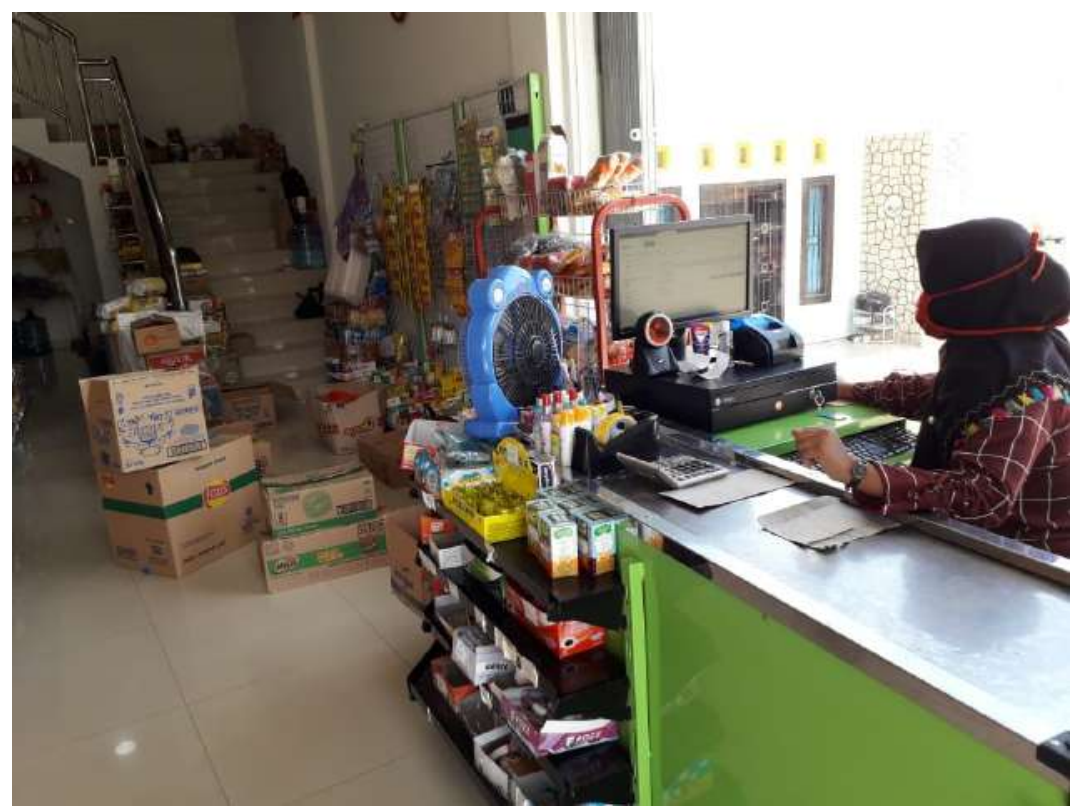

Gambar 8. Implementasi dan Pelatihan Sistem

CTo Maega / Jurnal Pengabdian Masyarakat. This is an open access article under the CC BY-SA 4.0 license (https://creativecommons.org/licenses/by-sa/4.0/). 
Setelah sistem siap digunakan, langkah terakhir yang dilakukan oleh tim pengabdian adalah memberikan petunjuk teknis penggunakan sistem dan mengadakan pelatihan bagi operator yang akan menggunakan sistem. Hal ini perlu dilakukan untuk memastikan bahwa operator dapat secara tepat dan benar menggunakan sistem tersebut. Pada saat memberikan pelatihan, tidak sepenuhnya berjalan dengan lancar, karena ada beberapa bagian tertentu yang membutuhkan tenaga dan fokus tambahan, seperti harus mengulang beberapa kali cara menggunakan sebuah modul didalam sistem yang operator tidak pahami.

\section{Kesimpulan}

Setelah melalui serangkaian tahapan kegiatan pengabdian, dapat diambil disimpulkan bahwa digitalisasi sangat diperlukan untuk membantu meningkatkan produktifitas kegiatan bisnis berbasis retail, karena aplikasi yang dibangun sudah sangat sesuai dengan karakteristik dan dapat digunakan oleh UMKM. Saran yang dapat disampaikan bahwa perlu pendampingan yang sangat khusus dalam memberikan pelatihan penggunaan aplikasi, terutama bagi UMKM yang sangat minim pengetahuan tentang teknologi. Selain itu perlu strategi yang sangat matang dalam proses publikasi sistem untuk menarik minat UMKM menggunakan sistem dalam kegiatan bisnisnya, terutama strategi untuk antisipasi jika terjadi bencana.

Untuk kegiatan pengabdian selanjutnya, UMKM perlu juga diberikan pembimbingan dan pelatihan membackup data-data yang diperlukan untuk strategi bisnis dikemudian hari.

\section{Ucapan Terimakasih}

Tim pengabdian mengucapkan terima kasih kepada Direktorat Riset dan Pengabdian Masyarakat (Ristekdikti) yang telah menyediakan program hibah pengabdian, sehingga dapat membantu UMKM mengembangkan bisnisnya. Tim pengabdian juga mengucapkan terima kasih kepada ISB Atma Luhur yang telah memberikan dukungan mengikuti kegiatan hibah tersebut.

\section{Daftar Pustaka}

Aji, R. (2016). Digitalisasi, Era Tantangan Media (Analisis Kritis Kesiapan Fakultas Dakwah dan Komunikasi Menyongsong Era Digital). Islamic Communication Journal. (1)1, 43-54.

Ardiansyah, M. A., \& Rudianto. (2018). Pengembangan dan Penerapan Teknologi Tepat Guna pada Industri Rumahan Pembuat Produk Lokal berbahan dasar Sagu di Kota Palopo. To Maega| Jurnal Pengabdian Masyarakat, (1)1, 29-34. 
Basuki, A. P. (2010). Membangun Web berbasis PHP dengan Framework Codeigniter. Yogyakarta: Lokomedia.

Destrianto, M. (2019, Agustus 23). Enggak Boleh Lengah, ini Kiat Agar UKM Bisa Sukses di Era Industri 4.0. Kompas. https://money.kompas.com/read/

Jaiz, Muhammad. (2014). Dasar-Dasar Periklanan. Yogyakarta: Graha Ilmu.

Mannuhung, S., Tenrigau, A. M., \& Didiharyono, D. (2018). Manajemen Pengelolaan Masjid dan Remaja Masjid di Kota Palopo. To Maega| Jurnal Pengabdian Masyrakat, (1)1, 14-21.

Ogedebe, P.M., \& Jacob, B.P. (2012). Software Prototyping: A Strategy to Use When User Lacks Data Processing Experience. ARPN Journal of Systems and Software. (2)6.

PPUPIK. (2019). Panduan Penelitian dan Pengabdian Kepada Masyarakat Edisi XII. Jakarta: Direktorat Riset dan Pengabdian Masyarakat.

Purnomo, Dwi. (2017). Model Prototyping Pada Pengembangan Sistem Informasi. Jurnal Informatika Merdeka Pasuruan, (2)2, 54-61.

Suriyati. (2019). Desain Perancangan E-Commerce Kain Tenun Lombok Desa Sukarara Lombok Tengah. To Maega| Jurnal Pengabdian Masyrakat, (2)2, $36-43$. 